\title{
The Possibility of the Jordanian Industrial Corporations to Apply the IFRS No. 15
}

\author{
Hasan Mahmoud Al-Shatnawi \\ Department of Accounting, Irbid National University, Jordan \\ E-mail: hsnshatnawi@gmail.com
}

Received: May 13, 2017 Accepted: June 11, $2017 \quad$ Published: June 11, 2017

doi:10.5296/ajfa.v9i1.11212ＵRL: http://dx.doi.org/10.5296/ajfa.v9i1.11212

\begin{abstract}
The goal of this study is to explore the possibility for the Jordanian industrial corporations to apply the International Financial Reporting Standers (IFRS) No. 15 from the point of view of the financial reporting preparers. To achieve the objectives of the study, a questionnaire was designed and distributed to a sample consisting of 84 individuals. Descriptive statistics were used to describe the study sample such as the frequencies, arithmetic mean, and standard deviation. In addition, the one-sample t-test was employed to test the study hypotheses at the 0.05 level of significance. This study showed that it is possible for the Jordanian industrial corporations to commit to the requirements for revenue recognition and the accounting measurement. As well as it is not possible commit to the requirements for the accounting disclosure of the revenues according to the IFRS 15. Furthermore, this study recommended to encouraging the corporations to commit to the requirements for revenue disclosure according to the IFRS 15 in such a way as to reinforce/foster trust of the users of the accounting information in the financial reports.
\end{abstract}

Keywords: IFRS 15, Revenue Recognition, Revenue Measurement, Revenue Disclosure, Jordanian Industrial 


\section{Introduction}

Accounting plays an essential and important role in efficiency of the capital markets and in influencing the investment decisions through the financial reports which the companies prepare. These reports must provide the correct and adequate information for the investors in the right time for taking their investment decisions. Usually, the accountants face the potential risks of bias and misinterpretation when preparing the financial reports. Based on this, use of the International Financial Reporting Standards (IFRSs) when preparing and processing the financial reports became a basic requirement for the different parties to reinforce transparency and lend them credibility (Aburman and Abdel latif, 2014).

Because of emergence of various fraud processes in recording the revenues at the time of disclosure, the present standards became relatively weak and inadequate to perform their desired purpose as the methods multiplied and the selling ways varied and no important changes in the accounting evidence emerged. This shortcoming in the accounting standards led the companies to manipulating their fixed revenues and inveigling the investor, viewer, and reviewer of the status of the company in ways that are consistent with old standards that do not satisfy the new developments in the working methods. Therefore, many court cases are raised against companies, especially the publicly-listed ones, and against the legal audit offices. Most of these cases concern the process of proving and recognition of the revenues. Hence, the international organizations specific to issuance of the accounting standards wakened and issued a new standard that organizes the revenue recording process and the time of recognition of them, which is the International Financial Reporting Standard No. 15 (IFRS 15): Revenue from Contracts with the Customers (Lim et al., 2015).

The IFRS 15 is considered as one of the modern and important standards that address the requirements for recognition, measurement, and disclosure related to the revenues from the contracts with the customers. This standard sets the principles of reporting the information useful for the users of the accounting information about the nature, amounts, timing, and uncertainty cases pertaining to the revenue and the flows emanating from the contracts with the customers. This standard came as an alternative to the international accounting standards No. 18 (Revenue) and No. 11 (Construction Contracts) because of the difficulty of applying these standards on the overlapping and complex cases for revenue recognition.

Significance of this study stems from its main subject, represented by the IFRS 15: Revenues from contracts with customers; its fundamentals, principles, and practical application. The study significance revolves around that this standard was issued under the umbrella of the efforts of convergence between the bodies specialized in setting the American accounting standards and those specialized in setting the international accounting standards, which leads to harmonization of methods and ways of the international accounting standards as this standard seeks to remove the cases of inconsistency and to present robust frame for dealing with those cases and improve the comparability and the disclosure requirements, and reduce the requirements for recognition of the revenue in preparation of the financial reports. As well, this study has academic significance represented in scarcity of the studies which addressed the IFRS 15 for preparation of the financial statements in view of modernity of the subject. It 
is hoped that the current study contributes to enrichment of the scientific library in the accounting area with theoretical substance at a high level of importance and modernity.

The IFRS 15 was issued in May 2014 to be put into practice in the first annual financial reports prepared on, or after, 1 January 2018. This standard came as a joint project between the international accounting standards board (IASB) and the American Financial Accounting Standards Board (FASB) to develop common requirements for revenues. Consequently, this study came to determine the possibility for the Jordanian industrial corporations to apply IFRS 15, which is related to the revenues of the contracts with the customers. The problem of the present study is investigating the commitment of the Jordanian industrial corporations to the requirements for revenue recognition, for the accounting measurement of revenues and for the accounting disclosure of revenues according to IFRS 15. As well as the commitment of the Jordanian industrial corporations to obstacles that prevent application of the IFRS 15.

The main goal of this study is to determining the potential for the Jordanian industrial corporations to apply IFRS 15. By studying its potential to commit to the requirements for revenue recognition and the accounting measurement of the revenues as well as the accounting disclosure of the revenues according to IFRS 15. As well as the basics, practical and principles of the IFRS 15 and the obstacles that prevent the Jordanian industrial corporations from applying the IFRS 15 will be studied. The remaining parts of this paper are organized as follows: section 2 and 3 presents a review of the recent, related literature and the research theoretical framework. Section 4 highlights the research design and the hypothesis building while section 5 describes the research methodology. Then, the last section lists the major findings of this study and discusses them and underlines the main conclusions of the present study and gives few recommendations.

\section{Literature Review}

Khamis (2016) "Perception of Preparers and Auditors of Revenue from Contract with Customer (IFRS 15): Evidence from Egypt", The main aim of this study was to check the differences between preparers and auditors in their observations of level of standard clarity, familiarity, and ease of application of IFRS 15 in various business segments in Egypt. This case study was depending on (i) individual interviews with the contributors who were requested to apply IFRS 15 and (ii) a questionnaire for them to record their levels of understanding with the standard. The final sample of this study contained of 34 preparers and 31 auditors across various business segments and sectors in Egypt. The study concluded that in common the Egyptian auditors and accountants surveyed were not yet set to adopt IFRS 15 and that they did not have adequate knowledge about IFRS 15. The researcher highlighted a need to improve skills and knowledge of the employees and a need for continuing training and education to improve the knowledge of the employees of the new international financial reporting standards.

Benavides (2015) "Flattening the Revenue Recognition Standard" This study examined both the future and the current standards of the U.S Generally-Accepted Accounting Principles (GAAPs) and discussed major areas of the new standard that will theatrically affect the financial reporting and processes sectors and segments of organizations. The researcher 
supports that the push back of the actual date is a sigh of comfort for all organizations to be affected by the new standards. The researcher underlined that neither the boards nor those organizations to be affected by the new revenue recognition standard were actually ready to adopt it on its initial efficient date. There is additional interpretation needed from the boards regarding to complex areas of the standard, and the organizations requisite to manipulate their infrastructure in order to successfully implement that standard.

Kasztelnik (2015) "The Value Relevance of Revenue Recognition under International Financial Reporting Standards" This research examined if there a main alteration in the value relevance of revenue recognition contents has occurred since adoption of the IFRS 15 in the United States. The study problem was the lack of recognizing of the value relation of revenue recognition under the IFRS and its application to influence the telecommunication industry. The results presented that revenue recognition in the public firms is value relation under the GAAP and that it remains so after adoption of the IFRS and that this leads to an increase in the value relation in the future.

Lim et al. (2015) "Perception of Auditors and Preparers of IFRS 15: Evidence from Malaysia" The main aim of the research was to check the differences between preparers and auditors in their levels of understanding, standard clarity, and ease of application across variance business segments and sectors in Malaysia. The five-step revenue recognition model has moved from the concept of 'risks and rewards' presently in practice to the concept of 'Control'. This is predicted to have influence on industries, especially those including long-term contracts with customers, since the style and timing of revenue recognition may be influenced. This study provided an overview of the perceptions of Malaysian auditors and preparers of the IFRS 15. Results of the study showed that the Malaysian accountants surveyed were not yet prepared to adopt the IFRS 15 and that they recognized that the standard is not easy to be implemented in various business sectors and segments.

Ismail (2014) "The Regulation of Financial Reporting: IC 15 and Revenue Recognition for Malaysian Property Developers" This research discussed the suggested IFRIC 15 in the context of Malaysia's financial reporting convergence trip for companies in the property improvement sector and segment. The sample consisted of 15 preparers and 15 auditors of financial reports of property makers. The study explored the change brought about when IC15 is adopted. The revenue recognition policy discovers in the annual reports of 113 property establishments presented that only 2 out of 133 establishments have adopted the suggested method in IFRIC15. This study contributed to the current discussion on convergence to IFRS and estimation of the benefits of convergence.

Dalkiliç (2014): "The Real Step in Convergence Project: A Paradigm Shift from Revenue Recognition to Revenue from Contracts with Customers" The objective of this research was two-fold, the first is to highlight the background and the history of the new standard; and, the second is to produce some policy recommendations for establishments on making ready for new standard. Results presented that industry-specific directing is missing. Thus, the new approach is heavily depending on professional judgment and contract terms and conditions. In addition, the new procedures will implement to all things that record into contracts with 
customers. That coming up with a mutual standard about revenue recognition is a main accomplishment for the standard producers, but for the company world the real work is fast oncoming. The first paragraph of the IFRS 15 establishes rules for reporting suitable information to users of financial statements about the amount, nature, uncertainty and timing of the revenue and cash flows growing from contracts of an entity with customers.

Mccarthy \& Mccarthy (2014): "Financial Statement Preparers' Revenue Decisions: Accuracy in Applying Rules-based Standards and the IASB-FASB Revenue Recognition Model" The objective of this study was to check financial managers' revenue decisions under a principles-based accounting standard in comparison to a rules-based accounting standard. This study experiment involved 127 experienced financial leaders with an average of 20 years of knowledge and experience. Eighty-two percent of those financial managers were at the level of manager or above. The results indicated that implementing rules-based standards affords less precise revenue decisions than implementing principles-based accounting standard. Furthermore, there was no statistically-significant variance in the amount of judgment requested between the subjects implementing rules-based standards and those implementing principles-based standards.

Hasanen et al. (2014): "A Proposed Model to Address Convergence Determinants, IFRS and FASB: Measurement and Disclosure of Revenue Recognition: "The Case of Egypt" This study focused mainly on the convergence of revenue recognition from contracts with customers, which was started in June 2010 and has since then been improved using wide-ranging due process rules into a nearly-finished product. Thus, this study demonstrated the effects of these convergence steps on the Egyptian accounting determinants and practice.

\section{Theoretical Framework}

This study framework is presented in the following sections:

\subsection{The International Financial Reporting Standards (IFRSS)}

The standards are defined as general obligatory models that lead to direction and rationalization of the practical application in accounting, auditing, or review of the accounts. Therefore, the standards differ from the procedures since the standards have the general obligation character while the procedures deal with the executive approach of these standards applied on certain empirical cases (Al-Gadi and Hamdan, 2008). Importance of the IFRSs points in what follows (Nawaal, 2011):

1) The IFRSs contribute to the process of control and organization of the accounting practice.

2) Presence of a subjective frame of the IFRSs governs that the measurement and communication guarantees achieving the balance between the different interests of the users of the financial reports.

3) Reliance on the IFRSs has a gig and necessary importance in the shade of failure of the accounting theories about treatment that prepares the accounting alternatives at the level of the economic establishment. 
4) Presence of the IFRSs helps the professionals and these standards specify their reactions under certain conditions. In addition, these standards are counted as a defense upon presence of interferences from, or supervision by, external parties.

One of the most significant factors that led to imparting importance and credibility to the IFRSs is the recognizing memorandum which was signed by the IASB and the American FASB for combined cooperation to remove the disagreement and discrepancy between the IASB and the FASB, and from which numerous IFRSs emanated. Of these is the IFRS 15 (Revenue from Contracts with Customers), which came as an alternative to the two international accounting standards IAS 18 (Revenue) and IAS 11 (Construction Contracts) because of the difficulty of implementing them to recognition of revenue for the sophisticated and overlapping cases.

This standard emerged as a combined project between the IASB and the American FASB to improve common requirements for the revenue topic that work on accomplishing the following objectives (Ciesielski and Weirich, 2011; Holzmann and Munter, 2014; Khamis, 2016):

1. Remove the several weaknesses and inconsistencies in current revenue requirements.

2. Provide a stronger framework of supervision that will be useful in manipulating revenue recognition problems and issues.

3. Enhance comparability of revenue practices among jurisdictions, entities, capital markets and industries.

4. Presents more suitable information to users of financial statements through enhanced disclosure requirements.

5. Simplify the preparation of the financial statements by decreasing the number of requests to that an entity necessity refers.

6. Joining international and U.S standards on revenue recognition.

The aim of IFRS 15 is to found the principles that an entity shall implement to report suitable information to users of the financial statements about the uncertainty, nature, amount of revenue and cash flows arising from a contract with a customer (IAS Plus).

\subsection{The Concept of Revenue According to IFRS 15}

Accounting is connected with projects that are continuous in operation and production, and not with one economic activity, and it divides the activity of the project into time periods and in the meantime attempts to devote to each accounting period its revenues and expenses. The revenues are represented in cash inflows or in growth of the assets of the accounting unit or its fulfillment of its obligations through production and delivery of the commodities during a certain period since accounting recognizes the revenue of the financial period in an independent manner, then the expenses in this period are measured for the purpose of determining the amount of income during the accounting period (Al-Qashi and Al-Aqla, 2015). 
Revenue is defined as the cash flows in flowing into the unit or any increase in its assets or settlement (reimbursement) of its discounts, or both, that result from production and sale of the goods and implementation of services for others or any other activities, which constitute the regular basic and continuous actions (Al-Shirazi, 1990).

The revenue is recognized in full at the point of completing the selling and delivery, i.e., upon incidence of actual exchange between the accounting unit and the others. At that point in time, the important event has taken place in the revenue acquisition cycle for the majority of the accounting units. In the meantime, the selling and delivery process provides objective indicator for measuring the revenue for the majority of the units, and it is possible to determine the degree of certainty or uncertainty through the possibility of procurement (Al-Naqib, 2004).

Revenue is measured on the basis of the fair value of the return which is received or is receivable. The value of the revenue resulting from any operation is determined by agreement between the establishment and the buyer or the user of the asset, and it is measured by the fair value of the received or receivable return, taking into consideration any commercial discount or quantity discount which the establishment bestows (Aburman, 2014).

3.3 The Accounting Requirements for Revenue Recognition and Measurement According to the IFRS 15

The fundamental principle of the IFRS 15 stands on that the establishment recognizes the revenue of the contracts that include diversion of the goods for an amount that represents the return which the establishment is expected to get inn return of that good which is diverted to the customer. According to this standard, the basic principle for revenue recognition takes place through application of the steps of the five-step model framework. These five steps are the following (Abu Nassar and Hamidat, 2016; Robert, 2015; Steele. 2012):

\section{Step 1: Identify the contract(s) with a customer}

This stage is considered as one of the accounting recognition stages as the contracts with the customers are considered as falling within the domain of this standard when they achieve all the following characteristics:

- Consent of the contract parties on the terms of the contract, in writing or orally or according to the generally-accepted practices within the business sector.

- The potentials for determining the rights of the contract parties as regards the goods transferred from one party to another in the contract.

- It is possible to determine the settlement provisions that are relating to the good provided by the establishment to the customer.

- The contract has commercial substance.

- It is possible that the establishment procures the return as a result of the contract of selling the good, taking into consideration the ability and desire of the customer to pay back. 


\section{Step 2: Identify the performance obligations in the contract}

This stage too is considered as one of the stages of accounting recognition. The establishment has at the beginning of the contract to evaluate the goods due to be presented to the customer according to the contract and determine them, considering them obligations that must be performed for the customer. The commodity is considered as distinguishable if the following two conditions are true:

- It is possible for the customer to benefit from the goods.

- Commitment of the establishment to deliver a commodity that is identifiable to the customer independently of any other obligations or promises in the contract.

\section{Step 3: Determine the transaction price}

This stage is considered as one of the stages of accounting recognition where the transaction price, which is the return which the establishment is expected to get in return of the process of selling the commodity, represents the obligations of the establishment appearing in the contract. It is also taken into consideration the practices prevalent in the industry when determining the price of the contract.

The return which the establishment is expected to get from the contract is influenced by several factors, including the changing return; presence of any funding element as a result of early settlement or a settlement paid in advance; presence of the non-cash return; and any return deserved by the customer.

As when the contract includes receipt of a changing return the establishment assesses the return expected to be received within the terms of the contract which results from several factors, including presence of discounts or allowances for the customer; presence of incentives in the contract, or presence of fines on the establishment in the contract. The changing return which expected to be received is listed in the price of the transaction only to the extent when listing it in the price of the transaction is highly likely not to lead to substantial reduction in the revenue in the future periods upon demise of the cases of uncertainty.

\section{Step 4: Allocating the transaction price to performance obligations}

If the contract contained several items of revenue, then the establishment has to distribute the overall price of the transaction over those constituents proportionally on the basis of the separate selling prices for each item in the contract. If those prices were unknown and clearly specified, then the establishment has to evaluate them. When the return in paid in advance or lately, then the establishment has to determine if the contract does, or does not, contain funding arrangements. Then, it is taken into consideration the time value of the period between the good and settlement of the recompense, and, consequently, considering any increase in the price of the operation over the cash selling price an interest revenue and any expenditure reduction as an interest. 
Step 5-Recognize revenue when the entity satisfies a performance obligation.

Revenue recognition takes place when the establishment performs the obligations and duties required from it through transferring the good to the customer. The transfer process occurs upon control of the customer over the asset and control over the revenue occurs either by passage of time (temporal basis), e.g., the rental income, or at a specified time point like selling of the ready commodity.

\subsection{The Accounting Requirements for Revenue Disclosure According to IFRS 15}

The goal of these disclosures is presenting information sufficient to enable the users of the accounting information to understand the nature and timing, amounts, and cases of uncertainty specific to revenue and the cash flows from the contracts with the customers. The IFRS 15 includes several disclosures that include (TYSIAC, 2014; Tong, 2015; Abu Nassar and Hamidat, 2016):

1) Disclosing quantitative and descriptive information about the contracts with the customers, such as

- The amount of revenue recognized.

- The impairment losses acknowledged any contract assets.

2) The important provisions and the estimates on them when applying the instructions of this standard on the contracts with the customers. In consequence, the establishment has to disclose: timing of performance obligations and transaction price and amounts assigned to performance obligations.

3) Any recognized assets resulting from the costs of gaining the contracts with the customers and accomplishment of those contracts. These include specification of:

- The amount of the costs incurred to get a contract with a customer.

- $\quad$ The method utilized for amortization.

- The closing stabilities of the contract assets.

\section{Research Design and Hypothesis Building}

As was noticed in the literature review and the theoretical framework, many studies presented the IFRS No. 15 and the possibility of applying it in the different organizations. The study of Lim et al. (2015) aimed to check the differences between preparers and auditors in their levels of understanding, standard clarity, and ease of application across variance business segments and sectors in Malaysia. This is predicted to have influence on industries, especially those including long-term contracts with customers, since the style and timing of revenue recognition may be influenced. The same methodologies are used by Khamis (2016) by checking the differences between preparers and auditors in their observations of level of standard clarity, familiarity, and ease of application of IFRS 15 in various business segments in Egypt. Ismail (2014) discussed the suggested IFRIC 15 in the context of Malaysia's financial reporting convergence trip for companies in the property improvement sector and 
segment. Therefore, based on foregoing arguments and the literature reviewed in this work, the present study aims to explore the possibility for the Jordanian industrial corporations to apply the IFRS No. 15 from the point of view of the financial reporting preparers. Therefore, the researcher poses the following hypotheses:

The First Hypothesis (H1): It is not possible for the Jordanian industrial corporations to commit to the requirements for revenue recognition according to the IFRS 15.

The Second Hypothesis (H2): It is not possible for the Jordanian industrial corporations to commit to the requirements for the accounting measurement of the revenues according to the IFRS 15.

The Third Hypothesis (H3): It is not possible for the Jordanian industrial corporations to commit to the requirements for the accounting disclosure of the revenues according to the IFRS 15.

The Fourth Hypothesis (H4): There are no obstacles that prevent the Jordanian industrial corporations from applying the IFRS 15.

\section{Research Methodology}

This study employed a quantitative research methodology. It aims to explore the possibility for the Jordanian industrial corporations to apply the IFRS No. 15 from the point of view of the financial reporting preparers

\subsection{Participants and Sampling}

In this study, the researchers employed non-probability techniques to collect the study sample because according to this method the researchers could distribute questionnaire forms to financial reporting preparers in the Jordanian industrial corporations. Thus, by using this technique the researchers could select the sample in the most convenient way. The study population includes the industrial companies listed on the stock exchange market in the Hashemite Kingdom of Jordan, which amounted to 64 companies during the period of the field study according to Amman Stock Exchange Market (ASEM). A random sample was taken, consisting of 100 individuals of the preparers of the financial reports for these companies. The questionnaire was distributed to those individuals. Eighty-four questionnaire forms were responded to and retrieved. All of them were valid for performing the study on them.

\subsection{Procedures and Data Collection}

This study relied on the analytical descriptive approach and depended on two sources for data collection, which are primary and secondary data. Saunders et al, (2007) defined the primary data as that data specifically collected for the research project being implemented. Thereupon, researchers use distinct methods to collect data that can help them reach to relevant findings and conclusions. Then, after the primary data have been collected they will be analyzed and distilled to make them useful such that the researchers can depend on their results to give appropriate, meaningful recommendations. For obtaining the primary data necessary for 
testing the hypotheses, a questionnaire was developed and arbitrated. It was embodied with a set of questions related to the study questions. The questionnaire was distributed to the members of the study sample. Descriptive statistics were employed to describe the study sample and the study hypotheses were tested using the one-sample t-test. In this study, both primary (self-completion questionnaire) and secondary data were employed. Nonetheless, the researchers used qualitative and quantitative data. After the research data had been managed, they were analyzed using the Statistical Package for Social Sciences (SPSS) software.

\subsection{Measurement}

The questionnaire was designed such that it will provide information about the possibility for the Jordanian industrial corporations to apply the International Financial Reporting Standers (IFRS) No. 15 from the point of view of the financial reporting preparers. Hence, feedback on the questionnaire is due to reflect the opinions of financial reporting preparers of the companies. The questionnaire used in the current study consisted of two parts:

1) Demographic part, which sought information about respondent's Academics qualification, Scientific specialization, experience and follow up of IFRS No.15.

2) Research part, which sought information about the possibility to apply the International Financial Reporting Standers (IFRS) No. 15 for the Jordanian industrial corporations.

\section{Data Analysis and Results}

This section presents results of analysis of the data collected using the questionnaire, which was addressed to financial reporting preparers in the Jordanian industrial corporations. The aim of the questionnaire was to explore the possibility to apply the International Financial Reporting Standers (IFRS) No. 15 for the Jordanian industrial corporations. A sample of 100 individuals of the preparers of the financial reports were distributed. Eighty-four questionnaire forms were responded to and retrieved. All of them were valid for performing the study.

\subsection{Normality Test}

The researcher tested for normality of distribution of this research variables using the Kolmogorov-Smirnov test. The test outcomes (Table 1) reveal that the study variables are normally distributed (Kolmogorov-Smirnov $\mathrm{Z}=1.084, \mathrm{p}=.190$ ). 


\section{Macrothink}

Table 1. Normality test. (One-Sample Kolmogorov-Smirnov Test)

\begin{tabular}{llc}
\hline & & Total \\
\hline $\mathrm{N}$ & & 84 \\
Normal Parametersa,b & Mean & 3.7143 \\
& Std. Deviation & .54078 \\
Most Extreme Differences & Absolute & .118 \\
& Positive & .118 \\
Kolmogorov-Smirnov Z & Negative & -.071 \\
\hline Asymp. Sig. (2-tailed) & & 1.084 \\
\hline
\end{tabular}

a. Test distribution is Normal.

b. Calculated from data.

\subsection{Reliability Test}

The internal consistency reliability was assessed using Cronbach's Alfa coefficient as an indicator of the reliability of the questionnaire items in terms of that they measure the aspects they were designed to measure in the answers of the members of the study sample as well as the instrument as a whole. The results of this test are summarized by Table 2. It is seen in Table 2 that the values of Cronbach's Alpha coefficient for the study domains and for the instrument as a whole are higher than 0.70 . This indicates a high level of reliability of the research instrument, which means the possibility of depending on the questionnaire results and reassurance to its credibility in achieving the study goals.

Table 2. Results of reliability analysis of the research instrument

\begin{tabular}{lc}
\hline Domain & Reliability Coefficient \\
\hline Requirements for recognition of revenue & 0.81 \\
Requirements for the accounting measurement of the revenue & 0.88 \\
Requirements for the accounting disclosure of the revenue & 0.75 \\
Obstacles to application of the IFRS 15 & 0.84 \\
The instrument as a whole & 0.89 \\
\hline
\end{tabular}

\subsection{Analysis of the Characteristics of the Study Sample}

The sample study consisted of 84 employees of Jordanian industrial corporations who were randomly selected from the study population. Table 3 summarizes distribution of the sample members depending on their personal characteristics. 


\section{Macrothink}

Table 3. Distribution of the sample members based on their personal characteristics

\begin{tabular}{llll}
\hline Variable & Categories & Frequency & percent \\
\hline Academic qualification & Diploma-College & 8 & $9.5 \%$ \\
& B.A & 61 & $72.6 \%$ \\
& M.A & 11 & $13.1 \%$ \\
& PH.D & 4 & $4.8 \%$ \\
& Total & 84 & $100 \%$ \\
\hline Scientific specialization & Accounting & 65 & $77.4 \%$ \\
& Banking and Financial & & $10.7 \%$ \\
& Sciences & & \\
& Business Administration & 8 & $9.5 \%$ \\
& Other & 2 & $2.4 \%$ \\
& Total & 84 & $100 \%$ \\
\hline Experience in the field of work & 5 Years OR Less & 20 & $23.8 \%$ \\
& 6 -10 Years & 43 & $51.2 \%$ \\
& $11-15$ Years & 11 & $13.1 \%$ \\
& 16 Years OR More & 10 & $11.9 \%$ \\
& Total & 84 & $100 \%$ \\
\hline Follow-up of the IFRSs issued & Ongoing & 40 & $47.6 \%$ \\
by the IASB & Medium & 23 & $27.4 \%$ \\
& Few & 14 & $16.7 \%$ \\
& None & 7 & $8.3 \%$ \\
& Total & 84 & $100 \%$ \\
\hline
\end{tabular}

Table 3 shows that:

- In terms of academic qualification, the highest number of respondents (72.6\%) was people with B.A qualification while people with $\mathrm{PhD}$ qualification were the lowest in number $(4.8 \%)$.

- With respect to scientific specialization, the majority of the respondents $(77.4 \%)$ were specialized in Accounting whereas the lowest percentage was that of individuals specialized in business Administration.

- As regards experience in the field of work, about half of the sample members $(51.2 \%)$ had 6-10 years of working experience. Meantime, the subject with having 16 years or more of working experience were the lowest in percentage (11.9\%).

- $\quad$ Regarding frequency of following up the IFRS, the relatively highest percentage of the respondents $(47.6 \%)$ was for the individuals with ongoing follow up of these standards. Individuals not following up these standards were the lowest in number $(8.3 \%)$.

\subsection{Descriptive Analysis}

Tables 4-7 provide a description of each of the study questions, showing the mean, standard deviation, and rank of each individual question. The results listed in these tables are discussed 
next. The respondents' mean total score of agreement on compliance of the Jordanian industrial corporations with the revenue recognition requirements of the IFRS 15 is high; 3.89. Table 4 shows that the highest mean score was 4.35 for Item 6 , which states that revenue is recognized when there is a high degree of certainty that the economic benefits associated with the contract will flow to the company. Meanwhile, the lowest mean agreement score (3.68), which is nonetheless high, was for Item 3, which states that the company specifies the terms of payment for the goods and services transferred from the establishment to the customer.

Table 4. Descriptive statistics for the questionnaire items related to compliance of the Jordanian industrial corporations with the revenue recognition requirements of the IFRS 15 .

\begin{tabular}{|c|c|c|c|c|c|}
\hline No & Items & Mean & $\begin{array}{l}\text { Standard. } \\
\text { Deviation }\end{array}$ & Rank & $\begin{array}{l}\text { Agreeme } \\
\text { nt Degree }\end{array}$ \\
\hline 1 & $\begin{array}{l}\text { The contract parties commit to implementing the terms of } \\
\text { the contract, whether they are written or oral. }\end{array}$ & 4.02 & 1.03 & 2 & High \\
\hline 2 & $\begin{array}{l}\text { The company can determine the rights of each party } \\
\text { regarding the goods and services transferred. }\end{array}$ & 3.83 & 1.07 & 4 & High \\
\hline 3 & $\begin{array}{l}\text { The company specifies the terms of payment for the } \\
\text { goods and services transferred from the establishment to } \\
\text { the customer. }\end{array}$ & 3.68 & 1.09 & 7 & High \\
\hline 4 & $\begin{array}{l}\text { The contract is classified in its essence as a commercial } \\
\text { contract, which affects the timing and amounts of the } \\
\text { cash flows for the contract. }\end{array}$ & 3.69 & 1.17 & 6 & High \\
\hline 5 & $\begin{array}{l}\text { The company procures the material return of the contract } \\
\text { as a result of the sale of the goods taking into } \\
\text { consideration the desire and ability of the customer to pay } \\
\text { back. }\end{array}$ & 3.90 & 1.06 & 3 & High \\
\hline 6 & $\begin{array}{l}\text { Revenue is recognized when there is a high degree of } \\
\text { certainty that the economic benefits associated with the } \\
\text { contract will flow to the Company. }\end{array}$ & 4.35 & 0.75 & 1 & High \\
\hline 7 & $\begin{array}{l}\text { At the beginning of the contract, the company evaluates } \\
\text { the goods it wishes to provide to the customer according } \\
\text { to the contract, and which are considered as part of the } \\
\text { fulfillment of the requirements of the contract. }\end{array}$ & 3.73 & 1.15 & 5 & High \\
\hline
\end{tabular}

\section{Total Means}

$3.89 \quad 0.49$

High

As Table 5 demonstrates, the respondents' mean total score of agreement on compliance of the Jordanian industrial corporations with the accounting revenue measurement requirements of the IFRS 15 is high; 3.96. Table 5 also shows that the respondents' highest mean agreement score (4.42) was for Item 4, which states that the establishment recognizes the revenue from the sale of goods upon transfer of control over the goods from the establishment to the customer. Alternatively, the lowest agreement score (3.60) was reported for the fifth item, which states that when there is a total discount, it is distributed over the items of the contract on the basis of the selling price and in a proportional way. 
Table 5. Descriptive statistics for the questionnaire items related to compliance of the Jordanian industrial corporations with the accounting revenue measurement requirements of the IFRS 15.

\begin{tabular}{clcccc}
\hline Items & Mean & $\begin{array}{c}\text { Standard. } \\
\text { Deviation }\end{array}$ & Rank & $\begin{array}{c}\text { Agreement } \\
\text { Degree }\end{array}$ \\
\hline $1 \quad \begin{array}{l}\text { The practices prevailing in the industry are taken into } \\
\text { consideration when determining the price of } \\
\text { the contract } \\
\text { When the payment is deferred, the revenues from sale } \\
\text { of the goods are recognized on the cash sale price and } \\
\text { the increase is treated as interest revenue. }\end{array}$ & 3.90 & 1.00 & 3 & High \\
$\begin{array}{l}\text { When the contract includes receipt of a changing } \\
\text { return, the company estimates the return and lists it } \\
\text { within the transaction price to some extent. }\end{array}$ & 3.67 & 1.07 & 5 & High \\
$\begin{array}{l}\text { The establishment recognizes the revenue from the } \\
\text { sale of goods upon transfer of control over the goods } \\
\text { from the establishment to the customer. }\end{array}$ & 4.42 & 0.73 & 1 & High \\
$\begin{array}{l}\text { When there is a total discount, it is distributed over the } \\
\text { items of the contract on the basis of the selling price } \\
\text { and in a proportional way. }\end{array}$ & 3.60 & 1.13 & 6 & Medium \\
$\begin{array}{l}\text { The establishment distributes the total transaction } \\
\text { price if the contract includes a total of revenue on the } \\
\text { basis of separate selling prices for each revenue item. }\end{array}$ & 4.19 & 0.83 & 2 & High \\
\hline$\quad$ Total Means & 3.96 & 0.78 & - & High \\
\hline
\end{tabular}

The statistical analysis results given in Table 6 bring to light that the sample members' overall total score of agreement on compliance of the Jordanian industrial corporations with the accounting disclosure requirements of the IFRS 15 is medium (2.94). Additionally, this table points out that the respondents' highest mean agreement score was medium (3.02) and related to the fifth item, which states that the establishment provides quantitative and descriptive information on any recognized assets resulting from the costs of obtaining and accomplishing contracts with customers. On the other hand, the lowest mean agreement score (2.56) was medium and associated with Item 7 (The entity shows information about the performance obligations arising from contracts with customers). 
Table 6. Descriptive statistics for the questionnaire items related to compliance of the Jordanian industrial corporations with the accounting disclosure requirements of the IFRS 15.

\begin{tabular}{|c|c|c|c|c|c|}
\hline No & Items & Mean & $\begin{array}{l}\text { Standard. } \\
\text { Deviation }\end{array}$ & Rank & $\begin{array}{l}\text { Agreement } \\
\text { Degree }\end{array}$ \\
\hline 1 & $\begin{array}{l}\text { The establishment shows the revenues from contracts } \\
\text { with customers separately from the other sources of } \\
\text { revenues for the establishment. }\end{array}$ & 3.63 & 1.22 & 1 & Medium \\
\hline 2 & $\begin{array}{l}\text { The establishment discloses the nature, timing, } \\
\text { amounts, and cases of uncertainties of related to } \\
\text { revenue and the cash flows from the contracts with } \\
\text { customers. }\end{array}$ & 2.80 & 1.14 & 5 & Medium \\
\hline 3 & $\begin{array}{l}\text { The establishment provides quantitative and } \\
\text { descriptive information about its contracts with the } \\
\text { customers and the methods used to recognize the } \\
\text { revenue. }\end{array}$ & 3.01 & 1.08 & 3 & Medium \\
\hline 4 & $\begin{array}{l}\text { The establishment provides quantitative and } \\
\text { descriptive information about the important rules and } \\
\text { evaluations which affect determination of the timing } \\
\text { and amounts of revenues from contracts with the } \\
\text { customers. }\end{array}$ & 2.88 & 1.17 & 4 & Medium \\
\hline 5 & $\begin{array}{l}\text { The establishment provides quantitative and } \\
\text { descriptive information on any recognized assets } \\
\text { resulting from the costs of obtaining and } \\
\text { accomplishing contracts with customers. }\end{array}$ & 3.02 & 1.24 & 2 & Medium \\
\hline 6 & $\begin{array}{l}\text { The establishment presents the opening and closing } \\
\text { balances of the accounts receivable, assets, and } \\
\text { liabilities arising from contracts with customers. }\end{array}$ & 2.69 & 1.21 & 6 & Medium \\
\hline 7 & $\begin{array}{l}\text { The entity shows information about the performance } \\
\text { obligations arising from contracts with customers. }\end{array}$ & 2.56 & 1.17 & 7 & Medium \\
\hline & Total Means & 2.94 & 0.75 & - & Medium \\
\hline
\end{tabular}

The outcomes of statistical analysis displayed in Table 7 disclose that the respondents' overall total score of agreement on the items pertaining to obstacles to application of the IFRS 15 by the Jordanian industrial corporations is high (4.17). Moreover, Table 7 points out that the sample members expressed the highest level of agreement (4.4) with the fourth listed obstacle, that is, management's lack of awareness of the importance of the IFRSs and the improvements on them. Meanwhile, the lowest mean level of agreement, which too was nonetheless high (3.96), was associated with the fifth listed obstacle, namely, inadequacy of the training programs held in the domain of the IFRSs and the most important amendments to them. 
Table 7. Descriptive statistics for the questionnaire items related to the obstacles to application of the IFRS 15 by the Jordanian industrial corporations

\begin{tabular}{|c|c|c|c|c|c|}
\hline No & Items & Mean & $\begin{array}{l}\text { Standard. } \\
\text { Deviation }\end{array}$ & Rank & $\begin{array}{l}\text { Agreement } \\
\text { Degree }\end{array}$ \\
\hline 1 & $\begin{array}{l}\text { Unavailability of the scientific and practical qualifications } \\
\text { sufficient for the employees of the financial department in } \\
\text { the industrial companies. }\end{array}$ & 4.10 & 0.96 & 4 & High \\
\hline 2 & $\begin{array}{l}\text { Difficulty in understanding and interpreting the } \\
\text { requirements of IFRS } 15 \text {. }\end{array}$ & 4.12 & 0.97 & 3 & High \\
\hline 3 & $\begin{array}{l}\text { There are no sufficient accounting systems to facilitate } \\
\text { the application of the accounting treatments specific to } \\
\text { revenue from contracts with customers. }\end{array}$ & 4.38 & 0.88 & 2 & High \\
\hline 4 & $\begin{array}{l}\text { Management's lack of awareness of the importance of the } \\
\text { IFRSs and the improvements on them. }\end{array}$ & 4.40 & 0.79 & 1 & High \\
\hline 5 & $\begin{array}{l}\text { Inadequacy of the training programs held in the domain } \\
\text { of the IFRSs and the most important amendments to } \\
\text { them. }\end{array}$ & 3.96 & 1.11 & 6 & High \\
\hline 6 & $\begin{array}{l}\text { Lack of adequate penalties by the financial market } \\
\text { regulators in the case of non-commitment to application } \\
\text { of the IFRSs. }\end{array}$ & 4.05 & 1.09 & 5 & High \\
\hline & Total Means & 4.17 & 0.72 & - & High \\
\hline
\end{tabular}

\subsection{Hypothesis Testing}

The First Hypothesis (H1): It is not possible for the Jordanian industrial public corporations to commit to the requirements for revenue recognition according to the IFRS 15.

This hypothesis was tested using the one sample t-test. The testing results (Table 8) uncover that the calculated $t$ value is 16.414 and that it is statistically significant $(p=0.000)$. Hence, the null hypothesis is rejected whereas the alternative hypothesis is accepted. This finding leads the researcher to the conclusion that it is possible for the Jordanian industrial corporations to commit to the requirements for revenue recognition according to the IFRS 15 .

Table 8. Results of the one-sample t-test of the first hypothesis

\begin{tabular}{lrrrrrr}
\hline & Mean & $\begin{array}{l}\text { Std. } \\
\text { Deviation }\end{array}$ & FD & t. value & Sig & $\begin{array}{c}\text { Result of the } \\
\text { null hypothesis }\end{array}$ \\
\hline H1 & 3.89 & 0.49 & 83 & 16.414 & 0.000 & rejected \\
\hline
\end{tabular}

The Second Hypothesis (H2): It is not possible for the Jordanian industrial corporations to commit to the requirements for the accounting measurement of the revenues according to the IFRS 15.

Much like in the case of the first hypothesis, the researcher tested soundness of the second hypothesis by using the one sample t-test. The outputs of this test (Table 9) reveal that the calculated $t$ value is 11.342 and that it is significant statistically $(p=0.000)$. Accordingly, the null hypothesis is rejected in favor of the corresponding alternative hypothesis, which is 
accepted. On account of this, the researcher conclude that is possible for the Jordanian industrial corporations to commit to the requirements for the accounting measurement of the revenues according to the IFRS 15.

Table 9. Results of the one-sample t-test of the second hypothesis

\begin{tabular}{ccccccc}
\hline & Mean & Std. Deviation & FD & t. value & sig & $\begin{array}{l}\text { Result of the } \\
\text { null hypothesis }\end{array}$ \\
\hline H2 & 3.96 & 0.78 & 83 & 11.342 & 0.000 & rejected \\
\hline
\end{tabular}

The Third Hypothesis (H3): It is not possible for the Jordanian industrial corporations to commit to the requirements for the accounting disclosure of the revenues according to the IFRS 15.

Table 10 presents the results of the one-sample t-test of the third hypothesis. It was found that the calculated $t$ value is -0.709 and that it is statistically non-significant $(p=.480)$. Based on this, the null hypothesis is accepted while the associated alternative hypothesis is rejected. Consequently, the researcher conclude that it is not possible for the Jordanian industrial corporations to commit to the requirements for the accounting disclosure of the revenues according to the IFRS 15.

Table 10. Results of the one-sample t-test of the third hypothesis

\begin{tabular}{ccccccc} 
& & & & & & $\begin{array}{l}\text { Result of the } \\
\text { null hypothesis }\end{array}$ \\
& Mean & Std. Deviation & FD & t. value & Sig. & \\
\hline H3 & 2.94 & 0.75 & 83 & -0.709 & 0.480 & accepted \\
\hline
\end{tabular}

The Fourth Hypothesis (H4): There are no obstacles that prevent the Jordanian industrial corporations from applying the IFRS 15.

Outcomes of the one-sample t-test of the fourth hypothesis are provided by Table 11. The researcher find that the calculated $t$ value is 14.857 and that it is statistically significant ( $p$ $=.000$ ). The null hypothesis is therefore rejected and the concomitant alternative hypothesis is accepted. In consequence, the researcher reach to the conclusion that it is are obstacles that prevent the Jordanian industrial corporations from applying the IFRS 15.

Table 11. Results of the one-sample t-test of the fourth hypothesis

\begin{tabular}{lllllll}
\hline & Mean & $\begin{array}{l}\text { Std. } \\
\text { Deviation }\end{array}$ & FD & t. value & Sig. & $\begin{array}{l}\text { Result of the } \\
\text { null hypothesis }\end{array}$ \\
\hline $\mathbf{H 4}$ & 4.17 & 0.72 & 83 & 14.857 & 0.000 & rejected \\
\hline
\end{tabular}

\section{Conclusions and Recommendations}

In view of the study findings, the researcher concludes the following: 
- It is possible for the Jordanian industrial corporations to commit to the requirements for revenue recognition according to the IFRS 15. Based on that, the contract parties will abide by specification and execution of the contract provisions, whether they were written or oral, and specification the obligations due to be implemented according to the contract.

- It is possible for the Jordanian industrial corporations to commit to the requirements of the accounting measurement of the revenues according to IFRS 15, and, in consequence, determine the price of the transaction through the return which they will get and distribute the transaction price over the components of the contract.

- It is not possible for the Jordanian industrial corporations to commit to the requirements for the accounting disclosure of the revenues according to the IFRS 15, since they do not adequately disclose the quantitative and descriptive information on the contracts with the customers as well as the important provisions and appraisals of them when applying the instructions of this standard.

- There are obstacles that prevent the Jordanian industrial corporations from applying the IFRS 15. Of these obstacles are (i) the difficulty in understanding and explaining the requirements of this standard; and (i) the lack of adequate accounting systems that facilitate application of the accounting treatments specific to the revenues according to this standard.

In view of the study recommendations, the researcher recomended the following:

- Encouraging the corporations to commit to the requirements for revenue disclosure according to the IFRS 15 in such a way as to foster trust of the users of the accounting information in the financial reports.

- Encouraging the corporations to provide sufficient accounting systems that facilitate application of the accounting treatments specific the IFRS 15.

- The financial market regulators are due to encourage the corporations to commit to application of the standards of the international financial reporting standards and to impose sufficient penalties in the case of non-compliance.

- Encouraging the corporations to provide accounting and financial cadre that is competent, qualified, capable, and with good knowledge of the measurement and recognition of the revenue generated from the income in the companies.

- Organizing training programs for the employees of the financial administrations in the Jordanian corporations on application of the international financial reporting standards and the accounting measurement methods, especially as regards the IFRS 15.

\section{References}

Abu Nassar, Mohammed, \& Hamidat Juma. (2016). International Accounting and Financial Reporting Standards, Dar Wael, Third Edition, Amman-Jordan.

Aburman, Shadi, \& Abdel Latif. (2014). Impact of Revenue Recognition Standard on the Accounting Problems in the Jordanian Construction Companies. unpublished master's thesis, 
Amman Arab University, Jordan.

Al Naqib, Kamal, \& Abdul Aziz. (2004). Introduction to Accounting Theory. Amman: Dar Wael Publishing

Alqadi, Hussein, \& Hamdan, Mamoun. (2008). International Accounting and Standards, Amman-Jordan, Dar Al-Thaqafa for Publishing and Distribution, First Edition.

Al-Qashi, Thaher Shaher, \& Al-Aqla, Mohammed Mansour. (2015). The Impact of Compliance of Revenue Recognition Principle on the Problems of Measuring Income Resources in Arab Satellite Channels. Algerian Journal of Accounting and Finance, 1.

Al-Shirazi, Abbas. Mahdi. (1990). Introduction to Accounting Theory. Kuwait: Al-Sallas for Printing and Publishing.

Amman Stock Exchange. (2017). http://www.ase.com.jo/ar/equities, 15/2.

Benavides, Luis. (2015). Flattening the Revenue Recognition Standard. Ssrn 2597787. 28 Apr. https://doi.org/10.2139/ssrn.2597787

Ciesielski, Jack. T., \& Weirich., Thomas. R. (2011). Convergence Collaboration: Revising Revenue Recognition. Management Accounting Quarterly, 12(3).

Dalkiliç, Ali Fatih. (2014). The Real Step in Convergence Project: A Paradigm Shift from Revenue Recognition to Revenue from Contracts with Customers. International Journal of Contemporary Economics and Administrative Sciences, 4(3-4), 67-84.

Hasanen, Mostafa, Hamed, Sadek, \& Abo Talib, Mohamed. (2014). A Proposed Model to Address Convergence Determinants, IFRS and FASB: Measurement and Disclosure of Revenue Recognition: The Case of Egypt. International Journal of Academic Research, 6(3), 269-285. https://doi.org/10.7813/2075-4124.2014/6-3/B.40

Holzmann, O. J., \& Munter, P. (2014). New Revenue Recognition Guidance. Journal of Corporate Accounting \& Finance, 25(6), 73-76. https://doi.org/10.1002/jcaf.21992

Ismail, Hashanah. (2014). The Regulation of Financial Reporting: IC 15 and Revenue Recognition for Malaysian Property Developers. International Journal of Business and Social Science, 5(13).

Kasztelnik, Karina. (2015). The Value Relevance of Revenue Recognition under International Financial Reporting Standards. Accounting and Finance Research, 4(3).

Khamis, Amr M. (2016). Perception of Preparers and Auditors on Revenue from contract with customer (IFRS 15): Evidence from Egypt. 35th International Business Research Conference 30 - 31 May 2016, American University in the Emirates, Dubai, UAE.

Saunders, M., Lewis, P., \& Thornhill. (2007). A. Research Methods for Business Students, Fourth Edition. Essex, England: Person Education Limited.

Lim, Y., Devi, S. S., \& Mahzan, N. (2015). Perception of Auditors and Preparers on IFRS 15: Evidence from Malaysia. Advanced Science Letters, 21(6), 1781-1785. 
https://doi.org/10.1166/asl.2015.6212

Mccarthy, M., \& Mccarthy, R. (2014). Financial Statement Preparers' Revenue Decisions: Accuracy in Applying Rules-Based Standards and the IASB-FASB Revenue Recognition Model. Journal of Accounting and Finance, 14(6), 21.

Robert A. (2015). Case Studies in the New Revenue Recognition Guidance. The CPA Journal, 85(3).

Sabayhi, Nawal. (2011). The Effect of Accounting Disclosure under International Accounting Standards (IAS) and its Impact on Information Quality", unpublished master's thesis, University of Algiers, Algeria.

Steele, C. A. (2012). The Convergence of US GAAP and IFRS: Revenue Recognition. Honors Theses, Paper 87.

Tong, Tan Liong. (2015). A Review of IFRS 15 Revenue from Contracts with Customers. See more

http://www.masb.org.my/pdf.php?pdf=2014-095\%20Review\%20of\%20IFRS\%2015\%20(TL T).pdf\&file_path=pdf

TYSIAC, KEN. (2014). Substantial new disclosures required by revenue standard. 